\title{
PSALM 145: LOOF JAHWE VAN A TOT Z
}

\author{
W.S. Prinsloo \\ Departement Ou Testament (Ned. Geref. Kerk) \\ Universiteit van Pretoria \\ PRETORIA
}

\begin{abstract}
Despite the absence of any clear strophic division, this acrostic is a remarkable poem. The poet employs numerous poetic techniques, notably the repetition of words. Psalm 145 could be described as a hymn. The poetic techniques sene to convey the contents of the psalm. It is a persuasive tex in which the poet sets out to persuade his readers or hearers that Yahweh should be proised for his greatness, sovereignty and love.
\end{abstract}

\section{INLEIDING}

'n Kommentator (Rogerson \& Mckay, 1977:176) merk van hierdie psalm op: "Probably no psalm in the whole Psalter is less in need of commentary than Ps. 145." Dit laat die vraag ontstaan of dit nog werklik nodig is om iets oor die psalm te sê as alles dan so glashelder is. Tog is hierdie psalm so ryk aan styl en inhoud dat 'n meas nie daaroor uitgepraat kan raak nie.

Daar is ook uiteenlopende menings oor die poëtiese en literêre gehalte van die psalm. Gunkel (1926:610) merk byvoorbeeld op dat hierdie psalm "mehr eine Künstelei als ein Kunstwerk" is. (Vgl. Van der Ploeg, 1974:478 wat kritiek op dié standpunt van Gunkel uitspreek.) Kittel (1914:486) is van mening dat die psalm geen duidelike gedagtegang vertoon nie. Die oordeel van Buttenweiser (1938:849) oor Psalm 145 is nog meer negatief: "Poetically the hymn is worthless. It appears to be a product of the time of literary decadence." Aan die ander kant is daar tog diegene (vgl. byvoorbeeld König, 1927:207) wat van mening is dat die psalm 'n logiese gedagtegang vertoon en as 'n kunswerk beskou kan word.

Ten einde op bogenoemde vrae en probleme ' $n$ antwoord te probeer gee, word ' $n$ volledige analise van Psalm 145 gemaak waarin aandag aan morfologiese, sintaktiese, stilistiese en semantiese fasette gegee word. In hierdie artikel word nie aandag aan sake soos die datering, outeurskap en redaksiegeskiedenis van Psalm 145 gegee nie. Dit beteken natuurlik nie dat dié sake onbelangrik is nie, maar in hierdie artikel val die klem op'n teksimmanente lees van die psalm. 
As hipotese word aangeneem dat ons wel hier met 'n kunswerk van hoogstaande gehalte te doen het. Soos by enige ander goeie gedig is die stylfigure en die poëtiese tegnieke wat gebruik word nie net dekoratief of ornamenteel van aard nie, maar is dit merkers wat heenwys na of wat ten dienste staan van die inhoud en boodskap (vgl. Berlin, 1985:17).

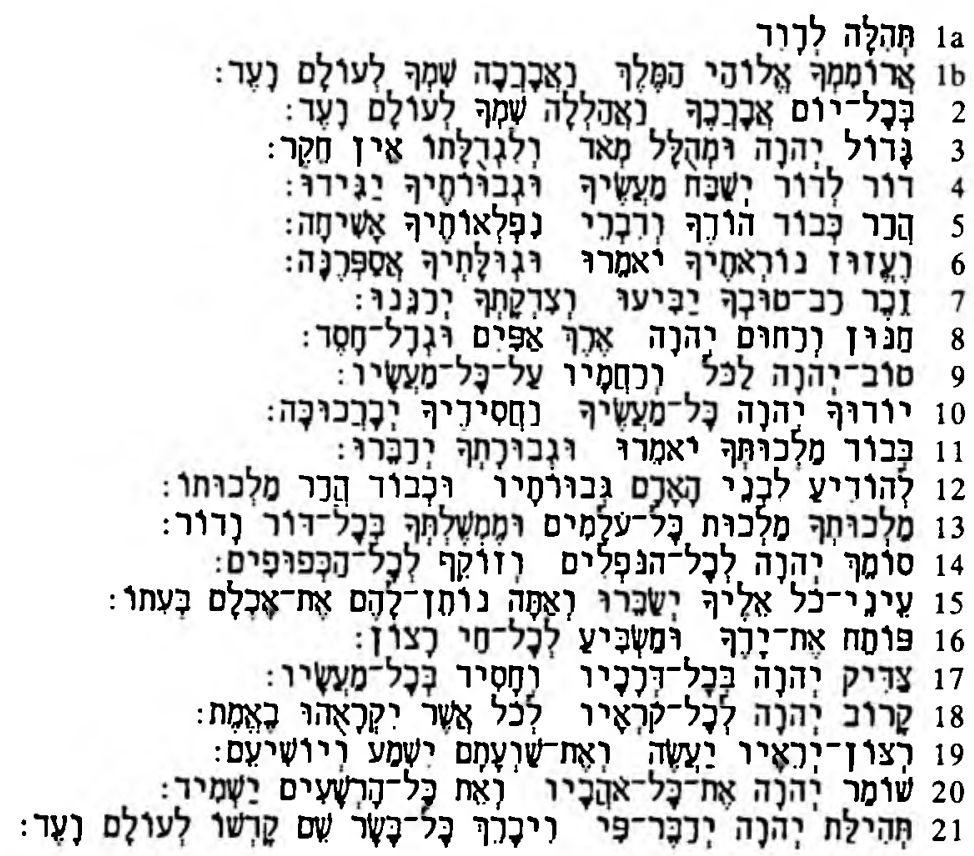

Die opvallendste kenmerk van Psalm 145 is die akrostigoniese of alfabetiese aard daarvan ${ }^{1}$. Dit is egter opmerklik dat die 2-reël ontbreek in hierdie psalm. Hoewel die

1 Munch (1936:708-710), wat die ontstaan van die akrostigon by wysheidskringe soek, is van oordeel dat die akrostigon oorspronklik 'n pedagogiese funksie gehad het waardeur leerlinge "durch deren Abschreiben das Alphabet und die Schönschrift gelernt werden sollte". Lindars $(1989: 23)$ is van oordeel dat die belangrikste rede vir 'n akrostigon artisties van aard is. Watson (1986:197-198) gee 'n goeie opsomming van die belangrikste funksies van die akrostigon: dit sou die voordeel inhou dat dit makliker gememoriseer kon word; deur die alfabetiese raamwerk te gebruik, het die digter vir homself 'n raamwerk geskep om in te werk. Hierdeur is hy in 'n sekere sin gebind, maar kon hy ook sy kreatiwiteit to uiting laat kom. Deur gebruik te maak van al die letters van die alfabet het die digter die gedagte probecr tuisbring dat hy aan al die fasette aandag gee en 'n bepaalde tema volledig bebandel. Spesifiek wat Psalm 145 se 
meeste kommentatore op grond van die $L X X$, die Siriese vertaling en 'n teks van die Qumrangrotte waar dié J-reël wel voorkom, van oordeel is dat dit bygevoeg behoort te word ${ }^{2}$, is daar tog diegene wat meen dat die uitlating van die J-reël doelbewus is en dat die Masoretiese teks so gelaat moet word (cf. byvoorbeeld Dahood, 1970:335; Watson, 1986:193). Dit is kenmerkend van die akrostigons van die Ou Testament dat letters van die alfabet dikwels uitgelaat of bygevoeg word sodat die ontbreking van die J-reël hier geen uitsondering is nie en die Masoretiese teks dus net so gelaat kan word.

'n Volgende opvallende kenmerk van die psalm is dat dit sowel ingelei as afgesluit

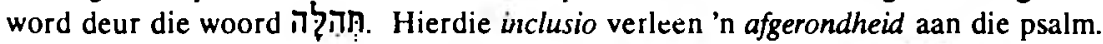
Die inclusio word nog verder versterk deurdat die werkwoordstam ברך, die woord


voorkom. Nog 'n kenmerk van die psalm, wat ook by ander akrostigons (bv. Ps. 112) voorkom, is die talryke woordherhalings (cf. Liebreich, 1956:181-192 wat die saak volledig bespreek). Soos wat aangetoon sal word, wend die digter ook 'n groot hoeveelheid stylfigure of poëtiese tegnieke aan.

\section{OPBOU, SAMEHANG EN POēTIESE TEGNIEKE}

$\mathrm{Na}$ hierdie inleidende opmerkings kan ons vervolgens in meer detail na die opbou van die psalm en na die verhouding van die verskillende stiges ${ }^{3}$ kyk:

Daar bestaan oorvloedige redes waarom 1b, 2 en 3 besonder nou aan mekaar verbind moet word. Dit is veral $1 b$ en 2 wat in 'n nou verbintenis tot mekaar staan: eerstens

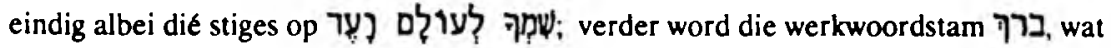
in die tweede hemistige van $1 \mathrm{~b}$ voorkom, in die eerste hemistige van 2 herhaal. Dié stylfiguur wat as staircase parallelism of anadiplose bekendstaan, bewerk verdere kohesie tussen $1 b$ en 2 . ' $n$ Verdere kenmerk van die twee stiges is die voluntatiewe

akrostigon betref, sluit Berlin (1985:18) bierby aan wanneer sy opmerk: "Rather it may have been used because it expresses a totality. The poet praises God with everyhing from $A$ to $Z$; his praise is all-inclusive."

2 Vcrgelyk byvoorbeeld Briggs \& Briggs (1909:527); Oesterley (1939:573); Kissane (1954:320); Kraus (1966:947); Rogerson \& McKay (1977:177); Deissler (1979:557); Anderson (1981:935); Allen (1983:294); Lindars (1989:24).

${ }^{3}$ Met stige word in hierdie artikel 'n versreël bedoel en met die term hemistige word na 'n versbeen verwys. 
werkwoordsvorme in die eerstepersoonenkelvoud ("Ek wil u lof verkondig...", "ek wil u Naam ... loof" [1b]; "... wil ek U loof", "ek wil u Naam ... prys" [2]). Samehangend hiermee is die opvallende alliterasie in sowel $1 \mathrm{~b}$ as 2 waar opeenvolgende werkwoorde met dieselfde medeklinker, naamlik $\boldsymbol{X}$ begin ${ }^{4}$. Die tweedepersoonenkelvoud-suffikse wat na God verwys, domineer ook in hierdie stiges. Inhoudelik handel $1 \mathrm{~b}$ en 2 oor die begeerte wat daar by die digter bestaan om die Here te loof. Hierdie gedagte word nog meer beklemtoon deur die parallelle opbou van $1 b$ :

Ek wil u lof verkondig ...//ek wil u Naam altyd loof

en deur die chiastiese opbou van 2:

Elke dag wil ek U loof//ek wil U loof vir altyd
a
b
b
a

3 sluit by die vorige stiges aan deurdat die werkwoordstam הל (loof) wat in 2 gebruik word, weer in 3 voorkom. In dié sin sluit 3 ook inhoudelik by die voorafgaande aan omdat dit hier om die lofwaardigheid van Jahwe gaan. 3 verskil egter van die vorige stiges daarin dat daar nie op 'n direkte wyse tot Jahwe gespreek word nie (vgl. die tweedepersoon-suffikse), maar dat daar in die derdepersoon oor Hom gepraat word. Anders as die vorige stiges, bestaan 3 uit nominale sinne ("Die Here is groot ...").

3 word egter ook by wyse van 'n opvallende woordherhaling aan die daaropvolgende dele van die psalm verbind. Die woord לרו ("groot", vgl. ook die tweede hemistige van 3, "sy grootheid", גורל (ג) wat 'n prominente rol in 3 speel, word weer in 6 ("u

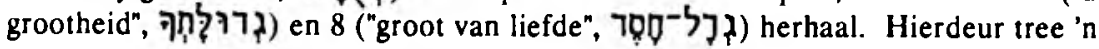
belangrike tema van die psalm, naamlik die grootheid van Jahwe, sterk op die voorgrond.

In 4 word die stylfiguur van foregrounding aangetref deurdat die uitdrukking לִ ("geslag vir geslag") voorop in die sinskonstruksie geplaas word. Hierdeur word beklemtoon dat die magtige dade van Jahwe "van geslag tot geslag" verkondig moet word. Die uitdrukking דרור word daar 'n inclusio tussen 4 en 13 bewerkstellig en die gedagte dat Jahwe voortdurend ("van geslag tot geslag") geprys moet word, word verder beklemtoon. In 13 gaan dit om die koningskap van Jahwe soos dit later sal blyk.

\footnotetext{
4 Watson (1986:196) toon aan dat alliterasie 'n tipiese kenmerk van akrostigons is. Dit blyk ook waar van Psalm 145 te wees. Vergelyk veral Psalm 145:10, 12, 13.
} 
Anders as 3 waar daar oor Jahwe in die derdepersoon gepraat word, is 4 gerig tot Jahwe in die tweedepersoon (" $U$ werke", " $U$ magtige dade"). 4 korreleer hierin met $1-2$, maar ook met 5, 6 en 7 waar die tweedepersoonsuffiks ten op sigte van Jahwe telkens voorkom (" $U$ majesteit", " $U$ magtige dade", 5 ; " $U$ wonderdade", " $U$ grootheid", 6 ; " $U$ goedheid", " $U$ geregtigheid", 7). Dit is eers weer in $\mathbf{8}$ dat daar in die derdepersoon van Jahwe gepraat word.

Wanneer die דור דור לור by 4 buite rekening gelaat word, vertoon dié stige 'n chiastiese opbou:

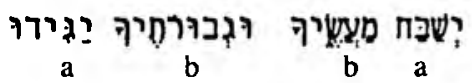

Hierdeur word beklemtoon dat die grootheid van Jahwe verkondig moet word. In aansluiting hierby moet die groot aantal woorde wat voorkom in die semantiese veld van verkondig/vertel/loof vermeld word: $\operatorname{loof}(1,2,10)$; prys (4,); verkondig (72J, 4);

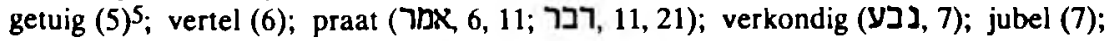
bekendmaak (12). Deur gebruikmaking van dié klomp woorde word die verkondiging van die grootheid/almag/koningskap van Jahwe tot een van die hooftemas van die psalm uitgelig.

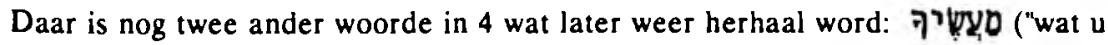
doen/u werke") word in 10 herhaal en in 9 en 17 kom dit weer voor net met die derdepersoonsuffiks ( מעy ר, "sy werke"). Dit spreek vanself dat hieruit afgelei kan word dat die digter deur dié herhalings 'n groot klem op die (lofwaardige) dade van Jahwe wou plaas. Die woord קברורסי ("u magtige dade) word ook nog twee keer aangetref in 11 en in 12 ("sy magtige dade").

In 5 word die tema van 4, naamlik die verkondiging van die heerlikheid van Jahwe voortgesit. Tussen 4 en 5 is daar ook 'n opvallende assonansie te bespeur wat die $\mathbf{0}-$, $\mathbf{e}$ -

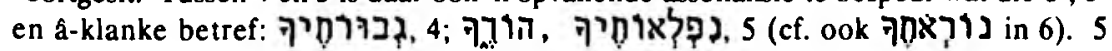

\footnotetext{
${ }^{5}$ Die konteks van Psalm 145 en die Qumranteks (11QPs") pleit daarvoor dat hier 1720? ("bulle sal getuig/vertel") in plaas van die MT 'כרך) ("en die sake van ...") gelees moet word. Die lesing word ook deur die LXX en die Siriese vertaling ondersteun. Vergelyk ook die volgende eksegete wat dié tekskritiese nota steun: Duhm (1899:296); Kirkpatrick (1903:815); Kittel (1914:486); Gunkel (1926:610); Schmidt (1934:252); Buttenweiser (1938:849); Oesterley (1939:573); Kissane (1954:320); Kraus (1966:947); Dabood (1970:337); Van der Ploeg (1974:481); Deissler (1979:557); Allen (1983:293).
} 
verskil egter daarin van 4 dat die digter nou in die eerstepersoon aan die woord is ( eindig op אפר ("ek wil vertel"). Hierdeur word daar natuurlik ook eindrym tussen 5 en 6 bewerk. Die twee hemistiges van 6 staan parallel:

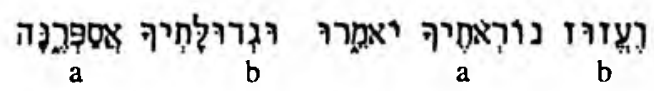

Die enigste verskil is dat die eerste hemistige melding maak van "hulle" en die tweede hemistige van "ek" wat van Jahwe moet getuig. In dié opsig vertoon 6 weer 'n verbintenis met 7 waar die derdepersoonmeervoudsvorm twee keer herhaal word:

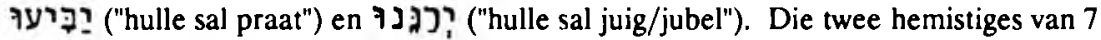
is parallel opgebou en vertoon ook eindrym. Hierdeur word die gedagte versterk dat die goedheid en geregtigheid van Jahwe verkondig moet word. Die woord "u

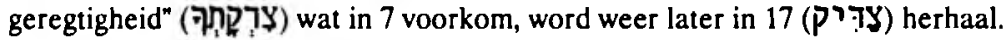

8 verskil van die direk voorafgaande stiges eerstens daarin dat daar nie direk tot Jahwe gepraat word in die tweedepersoon nie, maar wel in die derdepersoon. Tweedens, 8 is anders as die direk voorafgaande stiges 'n nominale sinskonstruksie. Hierin vertoon 8 'n ooreenstemming met 3 en met die volgende stige, naamlik 9 . Tog is 8 ook aan die voorafgaande gekoppel vanweë die heropname van die stam (vgl. ook 3,6). Dit is verder opvallend dat in $\mathbf{8}$ ' $\mathrm{n}$ aantal 'eienskappe' van Jahwe opgeneem word ten einde die goedheid van Jahwe te beklemtoon. Die eerste twee 'eienskappe' (סרוך) vertoon assonansie vanweë die a- en û-klanke. Die woord רญ् ("liefde", 1983-AV; "goedertierenheid", 1933/53-AV) blyk ook 'n sleutelwoord te wees deurdat dit in ietwat

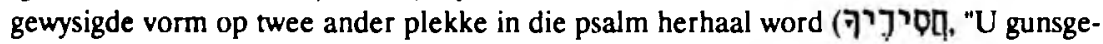
note", 10; 7णך, "goedgunstig", 17). Met 8 begin 'n tendens wat by 'n hele paar van die volgende stiges voortgesit word, naamlik dat die naam Jahwe in 'n prominente wyse redelik voorop in die sinskonstruksie geplaas word (vgl. 9, 10,14, 17, 18, 20, 21; vgl. ook 3). Hierdie patroon word eintlik net by $11-13$ en $15-16$ deurbreek. Dié aanwending van die naam Jahwe werk vanselfsprekend beklemtoning in die hand.

Ons het reeds gesien dat 9 , wat sinskonstruksie betref, nou by 8 aansluit. Dit geld ook van die tema wat hier aan die orde is. In 9 word die goedheid en barmhartigheid van Jahwe verder beskryf. Dit kom veral daarin tot uiting dat die stam $D \pi 7$ in sowel 8 as 9 voorkom. 9 gryp tematies egter ook na 7 terug deurdat die woord 1 , wat by laasgenoemde stige voorkom, in 9 herhaal word. Die twee hemistiges van 9 is parallel opgebou. Dit kan veral bemerk word in die herhaling van die woord 
almal"). Liebreich (1956:189-190) het tereg daarop gewys dat כל 'n sleutelwoord in die psalm is aangesien dit veelvuldig voorkom (vgl. behalwe 9 ook $1,10,13$ [2x], 14 [2x], 15, $16,17[2 x], 18[2 x], 20[2 x], 21)$.

Hoewel 10, anders as 9, weer eens direk in die tweedepersoon tot Jahwe gerig is (vgl. die vier tweedepersoon-suffikse waardeur assonansie bewerk word), is dit tog deur die stylfiguur van anadiplose aan 9 verbind: 7 ("al sy werke") kom in die tweede

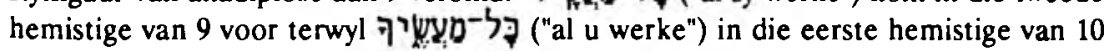
voorkom. Die stam ity speel ook'n prominente rol in die psalm (behalwe 9 en 10 , vgl. ook 4: "u werke"; 17: "sy werke"; 19: "Hy doen"). 10 as sodanig is ook chiasties opgebou:

Hulle loof $U$ al u maaksels/ $U$ gunsgenote prys $U$

a $\quad b \quad b \quad b \quad a$

Hierdeur word dit weer eens beklemtoon dat Jahwe geloof moet word (vgl. 1, 2 en 21 waar die werkwoord ברך ook voorkom). Dié gedagte word nog verder versterk deur die alliterasie by 10 waar die eerste twee woorde met ' begin.

Die volgende drie stiges, naamlik 11,12 en 13 is baie nou aan mekaar verbind aan-

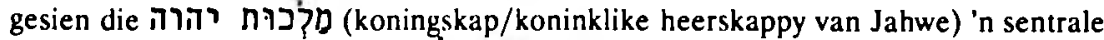
rol daarin speel. Die woord מלכר מלכו kom in elkeen van die drie stiges voor. In terme van die plasing van dié woord het Lindars (1989:26) tereg opgemerk dat dit in die eerste deel van 11 , in die laaste deel van 12 en weer in die eerste deel van 13 voorkom, dus:

12

\section{1}

13

Die plasing van die woord מל מלכרד vertoon dus 'n driehoek6. Verder is daar al deur etlike eksegete (Ceresko, 1978:6; Watson, 1981:102; Berlin, 1985:19) daarop gewys dat die drie stiges $(11,12$ en 13$)$ 'n chiasme vorm wat die plasing van die woorde betref:

6 In die woorde van Lindars (1989:26): "Viewed from the point of the pattern on the page, the occurences of malkût in these three verses make a triangle with apex at the left:" 


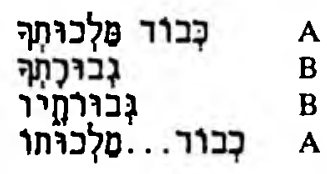

Watson (1981:102) wys verder daarop dat daar ook ten opsigte van die afwisseling van manlike en vroulike vorme in 11-12 'n chiastiese patroon bespeur kan word. Deur dié chiasmes word die magtigheid van Jahwe se koningskap nog meer beklemtoon.

Die opvallendste kenmerk van 11, 12 en 13 is egter wat Watson (1981:101) "reversed rootplay" noem. Die akrostigoniese letters van 11-13, naamlik J, 5 en D maak מלכ מלך uit

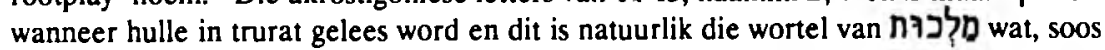
wat ons reeds gesien het, die belangrikste tema van 11-13 is ${ }^{7}$. In die lig van die talle stylfigure wat reeds deur die digter gebruik is, kan hierdie geval geen toevalligheid wees nie, maar is dit nog 'n manier om die koningskap van Jahwe te beklemtoon.

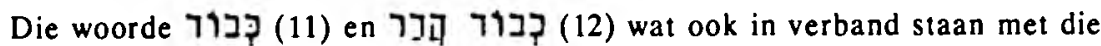
heerlikheid van Jahwe se koningskap, lê 'n verband met 5 waar 'n soortgelyke uitdrukking voorkom (בכר כבכרוך).

11 se twee hemistiges is parallel opgebou:

Oor die heerlikheid van u koningskap praat hulle

Oor u mag spreek hulle

Deur die parallelisme word onderstreep dat die heerlikheid van die koningskap van Jahwe verkondig moet word. Die gedagte word verder in 12 uitgebou. Dahood דבור בכר מלכרוnו) 12 (1970:338) dui met reg aan dat die hele tweede hemistige van "die glansryke heerlikheid van sy koninkryk") 'n uitbouing is van slegs die derde

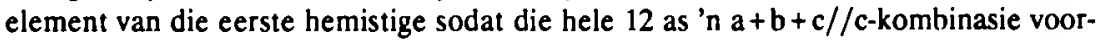
gestel kan word. Deur die uitbouing van element $c$ (die koningskap van Jahwe) word dié tema nog 'n keer beklemtoon. 'n Stylfiguur wat heel dikwels by 'n akrostigon

\footnotetext{
${ }^{7}$ Berlin (1985:19, voetnoot 4) verskil egter van Watson. Sy stel dit soos volg: The placement and arrangement of these letters would seem to be more a factor of the alphabetic acrostic rather than a desire for a reverse acrostic of mlk. More persuasive of the importance of the kingship theme is the use of mlkwt in vv 11, 12:" Soos hierbo angetoon, kan die feit dat die omgekeerde $m / k$-akrostigon juis hier voorkom waar dit oor die koningskap van Jahwe gaan nie toevallig wees nie, maar is dit eerder 'n doelbewuste stylfiguur van die digter.
} 
voorkom, naamlik alliterasie, word ook hier aangewend deurdat die eerste twee woorde van 12 met die medeklinker $ל$ begin.

13 is parallel opgebou:

U koningskap is 'n koningskap vir altyd

U heerskappy duur van geslag tot geslag

Hierdie parallelisme onderstreep die permanensie en voortdurendheid van die koningskap van Jahwe. Die koningskap van Jahwe word ook onderstreep deur die alliterasie deurdat die eerste twee woorde van 13 ("U koningskap is 'n koningskap ...") met die

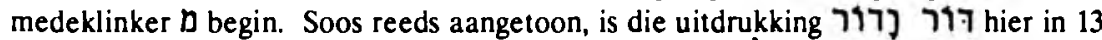
'n heropname van feitlik dieselfde uitdrukking in 4 (דרור לדור). Hierdeur word 'n verband gelè tussen die voortdurendheid van Jahwe se magtige dade en die voortdurendheid van sy koningskap.

By 14 tree daar 'n nuwe element na vore wat sover nog nie in die psalm bemerk is nie, naamlik dat die handelinge van Jahwe by wyse van partisipia beskrywe word. Dit is ' $n$ tipiese kenmerk van himnes om die handelinge van Jahwe so op 'n partisipiale wyse te beskryf om daarmee die lofwaardigheid van Jahwe nog meer na vore te laat tree. Die volgende partisipia kom voor: סומר (ondersteun), נורקו (gee), 15;



14 is parallel opgebou:

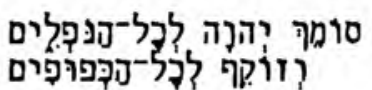

("Die Here ondersteun almal wat geval het//en Hy tel dié wat neergeboë is $o p^{\prime \prime}$ )

Die twee hemistiges vertoon ook eindrym deurdat albei op -im eindig. Die parallelisme beklemtoon Jahwe se mededoë met die personae miserae. Dié tema word voortgesit in 15 en 16. In 15-16 is die tema spesifiek Jahwe wat voed. In beide stiges val die klem op die feit dat almal en alles van Jahwe afhanklik is vir hulle voedsel. 15 en 16 is egter om nog ' $n$ rede baie nou verbind: anders as die voorafgaande 14 en die daaropvolgende 17-20 wat in die derdepersoon oor Jahwe praat, word in 15-16 die tweedepersoonsvorm gebruik en is dus direk tot Jahwe gerig. 'n Kenmerk van 14-16 is dat dit in vergelyking met die res van die psalm waar woordherhalings dominant voorkom, feitlik geen woordherhalings bevat nie. Die enigste uitsonderings is die partikel 
("alle/almal"; vgl. hierbo by die bespreking van 9 waar die voorkoms van dié partikel in die res van die psalm bespreek word) en die woord 7 ב ook in 19 voorkom.

17 en 18 is om verskeie redes nou aan mekaar verbind: anders as die voorafgaande 15 en 16 word hier weer van Jahwe in die derdepersoon gepraat. 17 en 18 se eerste hemistiges is albei nominale sinne en is sintakties parallel opgebou:

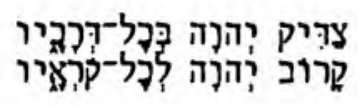

17 se twee hemistiges as sodanig is ook parallel opgebou:

Regverdig is die Here in al sy weë

Goedgunstig (is die Here) in al sy dade

Deur dié parallelisme en deur die herhaling van twee sleutelwoorde wat reeds voor-

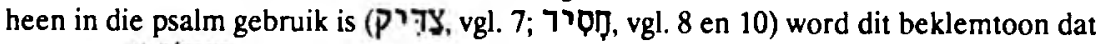
die dade ( ר stam itty in die psalm) van Jahwe "regverdig" is.

18 se twee hemistiges vertoon ook parallelle trekke. Om dit meer korrek te stel, die tweede hemistige is parallel aan en is ' $n$ verdere uitbouing van die tweede deel van die eerste hemistige ${ }^{8}$ :

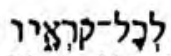

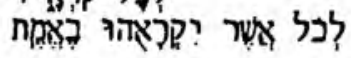

Die herhaling van die werkwoord $\mathrm{P}$ is veral opvallend in die stige. 18 neem die tema van 14-16, naamlik dat Jahwe naby diegene is wat in nood is, weer op en kwalifiseer dit: Jahwe is naby diegene wat Hom "in waarheid" (ת) aanroep.

19 en 20 kontinueer die derdepersoonenkelvoud-suffikse (verwysende na Jahwe) van 17 en 18, maar verskil tog daarin dat hier nie nominale sinne is nie. 'n Kenmerk van veral 18, maar ook van 19 is dat hier ' $n$ hele aantal werkwoorde gebruik word om die handeling van Jahwe te beskryf. Samehangend hiermee is die alliterasie, want dit is

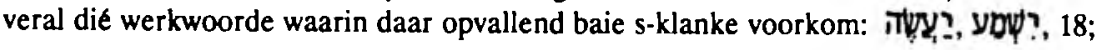

\footnotetext{
${ }^{3}$ Dahood (1970:338) wys dus tereg daarop dat 18 die $a+b+c / / c$-patroon van 12 berhaal.
} 


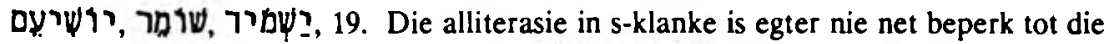

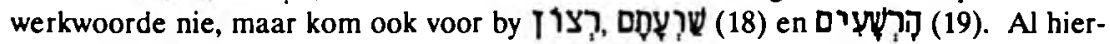
die stylfigure beklemtoon enersyds die ingryping van Jahwe ten behoewe van dié wat Hom liefhet, maar andersyds die verdelging van die goddeloses. Dié kontras word nog meer beklemtoon deurdat 20 chiasties opgebou is:

Die Here bewaar dié wat Hom liefhet

a

b

maar die goddeloses verdelg $\mathrm{Hy}$.

b

a

Die kontras word nog meer versterk deur die woordspel by die twee werkwoorde wat hier gebruik word, naamlik שואר ("bewaar") en ("verdelg"). Die ר van die eerste werkwoordstam word in die tweede werkwoordstam slegs met 'n 7 vervang, maar tog verskil die betekenis van die werkwoorde diametraal.

Daar is reeds daarop gewys die dat psalm 'n inclusio vorm deurdat 21 sterk coreenkomste met die begin van die psalm vertoon.

\section{SAMEVATTING}

$\mathrm{Na}$ hierdie analise kan daar nou samevattende opmerkings oor die psalm gemaak word:

\subsection{Geen afgebakende strofe-indelings nie}

Hoewel die analise aangetoon het dat sekere stiges nouer aan mekaar verbind is as ander, is daar werklik geen duidelik, afgebakende strofe-indelings nie. Dit lyk eerder asof ons hier te doen het met ' $n$ ingewikkelde netwerk van verhoudings waarin een deel van die psalm telkens met ' $n$ ander deel verbind word deur allerlei poëtiese tegnieke. Hier speel woord- en fraseherhalings veral 'n belangrike rol. Ons het hier dus iets soos skakels van ' $n$ ketting wat die een met die ander verbind - of om dalk nog ' $n$ beter beeld te gebruik - iets soos die ingewikkelde samestelling van ' $n$ tapisserie. Hierdie kenmerk van die psalm hang waarskynlik daarmee saam dat ons hier met ' $n$ akrostigon te doen het. Dit is nie ongewoon vir 'n akrostigon dat daar 'n duidelike strofe-indeling ontbreek nie (vergelyk byvoorbeeld Psalm 112). Die gebrek aan 'n duidelike strofe- 
indeling beteken dus nie dat daar geen samehang in die psalm bestaan nie. Dit beteken ook nie dat ons hier te doen het met 'n minderwaardige gedig nie. Soos aangetoon, kom daar talle poëtiese tegnieke in hierdie psalm voor sodat ons kan praat van 'n gedig van hoë poëtiese kwaliteit.

\section{Temas}

Wanneer daar na die gedig in sy totaliteit gekyk word, tree die volgende belangrike temas na vore:

- Die totale gedig word beheers deur die digter se begeerte om Jahwe voortdurend te loof. Die lof moet aan almal en orals verkondig word.

- Jahwe se grootheid, die grootheid van sy werke, die grootheid van sy liefde, sy barmhartigheid en genade, sy liefde en geregtigheid, sy liefdevolle en daadkragtige hulp aan die wat in nood is, sy heerlikheid, en veral sy koningskap word sterk in die psalm beklemtoon. Al die 'eienskappe' van Jahwe word gebruik as motivering waarom Hy geloof moet word.

- Hoewel Psalm 145 dit beklemtoon dat die Here die Bewaarder is en dat Hy deernis het met dié wat in die nood is, is sy bewaring nie onvoorwaardelik nie. Hy bewaar dié wat Hom liefhet, maar verdelg die goddelose.

Dié temas staan nie los van mekaar nie, maar is vanweë die samestelling van die psalm onlosmaaklik met mekaar verweef en speel op verskillende maniere op mekaar in. So word die grootheid en almag van Jahwe byvoorbeeld met sy liefde in verband gebring; sy goedheid en genade is nie in botsing met sy toorn nie, maar slegs die keersy van dieselfde muntstuk; die koningskap van die Here word in dieselfde asem genoem as sy neerbuigende liefde teenoor die wat in nood is.

\subsection{Literatuursoort}

Wat die genre of literatuursoort van die psalm betref, kan ons met sekerheid sê dat ons

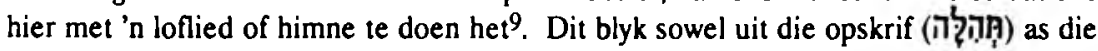

${ }^{9}$ Daar word natuurlik ook pogings aangewend om dié genre nog nader te omskryf. Westermann (1963:98) praat van Psalm 145 as een van die "Imperativ-Psalmen" terwyl Crüsemann (1969:296) dit tipeer as een van die "Hymnen eines Einzelnen". 
res van die psalm. Globaal gesproke, bestaan die psalm uit imperatiewe en kohortatiewe om Jahwe te loof en is die beskrywing van al Jahwe se eienskappe eintlik 'n motivering waarom $\mathrm{Hy}$ geloof moet word. Aansluitend hierby kan ons oor die funksie van die psalm sê dat dit 'n oorredende teks is omdat alles in die psalm ten doel het om die leser/hoorder te oorreed dat Jahwe lofwaardig is en dat Hy geloof moet word.

Om alles weer saam te vat: Jahwe moet orals, deur almal geloof word omdat sy liefde, sy almag, sy grootheid, sy koningskap en werke alles en almal omvat. Ten einde dié boodskap tuis te bring, maak die digter van die akrostigon en talle ander poëtiese tegnieke gebruik. Ons het dus sowel wat vorm as inhoud betref, te doen met 'n gedig van hoogstaande gehalte.

\section{BIBLIOGRAFIE}

ALLEN, L. C. 1983. Psalms 101-150. Waco, Texas : Word Books (Word Biblical Commentary 21)

ANDERSON, A. A. 1981. Psalms (73-150). Grand Rapids: Eerdmans (New Century Bible Commentary).

BERLIN, A. 1985. The rhetoric of Psalm 145. (In Kort. A. \& Morschauser, S., ed. Biblical and related studies presented to Samuel Iwry. Winona Lake, Indiana : Eisenbrauns. p. 17-22.)

BRIGGS, C. A. \& BRIGGS, E.G. 1909. The book of Psalms. Edinburgh : T \& T Clark (The International Critical Commentary)

BUTTENWEISER, M. 1938. The Psalms. Chicago : The University of Chicago Press.

CERESKO, A. R. 1978. The function of chiasmus. Catholic Biblical Quanerly, 40: 1-10.

CRüEMANN, F. 1969. Studien zur Formgeschichte von Hymnus und Danklied in Israel. NeukirchenVluyn : Neukirchener Verlag (Wissenschaftliche Monographien zum Alten und Neuen Testament 32).

DAHOOD, M. 1970. Psalms III. New York: Double Day (The Anchor Bible 17a).

DEISSLER, A. 1979. Die Psalmen. 2. Aullage. Düsseldorf : Patmos Verlag.

DUHM, B. 1899. Dic Psalmen. Freiburg/Lciprig/Tubingen : Mohr (Kurzer Hand-Commentar XIV).

GUNKeL, H. 1926. Die Psalmen. 4. Aufl. Götlingen : Vandenhocek \& Ruprecht (Götinger Handkommentar zum Alten Testament II/2).

KIRKPATRICK, A. F. 1903. The book of Psalms. Cambridge : Universily Press.

KISSANE, E. J. 1954. The book of Psalms. Dublin : Browne \& Nolan.

KITTEL, R. 1914. Die Psalmen. 1. und 2. Auflage. Leipzig : Deichertsche Verlagsbuchhandlung (Kommentar zum Alten Testament XIII).

KöNIG, E. 1927. Die Psalmen. Gütersloh : Bertelsmann.

KRAUS, H. J. 1966. Psalmen 2. Teilband 3. Unveränderte Auflage. Neukirchen : Neukirchener Verlag (Biblischer Kommentar Altes Testament XV/2).

LIEBREICH, L. J. 1956. Psalms 34 and 145 in the light of their key words. Hebrew Union College Annual, 27: 181-192.

LINDARS, B. 1989. The structure of Psalm CXLV. Vetus Testamentum, 29(1): 32.30.

MUNCH, P. A. 1936. Die alphabetische Akrostichie in der jüdischen Psalmendichtung, Zeitschrift der Deutschen Morgenlandischen Gesellschaft, 90: 703-710. 
Psalm 145: Loof Jahwe van $A$ tot $Z$

OESTERLEY, W. O. E. 1939. The Psalms II. New York : Macmillan.

ROGERSON, J. W. \& Mckay, J. W. 1977. Psalms 101-150. Cambridge : Cambridge University Press.

SCHMIDT, H. 19.34. Die Psalmen. Tubingen : Mohr (Handbuch zum Alten Testament 2).

VAN DER PLOEG,J. P. M. 1974. Psalmen II. Rocrmond : Romen \& Zonen (De Bocken van het Oudc Testament VIIb).

WATSON, W. G. E. 1981. Reversed rontplay in Psalm 145. Biblica, 62 (1): 101-102.

WATSON, W. G. E. 1986. Classical Hebrew poctry. A guide to its techniques. 2nd edition. Sheffield: The University of Shefficld (Journal for the Study of the Old Testament Supplement Series 26).

WEstermanN, C. 1963. Das Loben Gottes in den Psalmen. 3. Auflage. Göttingen : Vandenhoeck \& Ruprecht. 